\title{
JESSE SHERA, THE WARS AND THE PIETÁ: SOCIAL EPISTEMOLOGY AS CRITICISM OF INFORMATION ONTOLOGY
}

\author{
Rodrigo Porto Bozzetti (1), Gustavo Saldanha (2)
}

(1) Instituto Brasileiro de Informação em Ciência e Tecnologia (IBICT), Universidade Federal do Estado do Rio de Janeiro (UNIRIO) bozzetti.rb@gmail.com, (2) saldanhaquim@gmail.com

\begin{abstract}
Resumo
O objetivo deste trabalho, reconhecida a relevância do pensamento sheriano e suas repercussões, é reposicionar, em termos epistemológico-históricos, as abordagens de Jesse Shera e seus impactos segundo uma relação entre vida e obra do epistemólogo. Sem o intuito de uma discussão exaustiva, o propósito delineado está em compreender, segundo uma via filosófico-pragmática, algumas relações entre a crítica de Shera para o contexto de sua formulação teórica e as consequências desta abordagem contrária a algumas tendências oriundas das raízes técnico-burocráticas do campo (antes e depois da Segunda Guerra Mundial). Em certa medida, a partir da reflexão, depreende-se como Shera, mais do que observar a realidade sócio política e sócio técnica na qual estava inserida a tessitura de um pensamento biblioteconômico (mas já visualizada por ele na mutação teóricoterminológica como documentalista-informacional), estabelece, em sua própria práxis, a epistemologia social como uma espécie de "crítica do futuro", ou seja, como práxis da atividade reflexiva do sujeito inserido nesta episteme. A abordagem epistemológico-social representa, em nossa discussão, uma vanguarda para o contexto de sua afirmação, uma reavaliação para as décadas imediatas à sua apresentação (anos 1960 e 1970) e uma crítica para o futuro do que se consolidou sob a noção de information science, antecipando afirmações de "cunho social" dos anos 1980 e 1990 no campo informacional.
\end{abstract}

Palavras-chave: Jesse Shera. Epistemologia Social. Epistemologia Histórica. Filosofia da Informação. Ciência da Informação.

\section{Introduction}

Librarians would do well to remember occasionally Moses or a Pietá and think somewhat less frequently Shannon and Weaver. (Shera, 1983, p. 385)

Considering the demarcated neo-liberal background transformations between the 1960s and 1970s in the United States and the military-financial power of the concept of "information" in this context, Jesse Shera's theoretical argument has been diluted in a possible, ahistorical approach. Attempts to approach a historiographical construction of the librarianshipinformational field invariably established this principle of silencing. We can verify this approach in revisions such as Miksa (1992), Capurro (2003) and Rendón

\begin{abstract}
The purpose of this paper, considering the relevance of Shera thoughts and its repercussions, is to reposition, in epistemological-historical terms, Jesse Shera's approaches and their impacts according to a relation between life and work of the epistemologist. Without the intention of an exhaustive discussion, the purpose is to understand some unequivocal relations between the Shera critique for the context of its theoretical formulation and the consequences of this approach contrary to some tendencies originating from the technical and bureaucratic roots of the field (before and after World War II). It is deduced that Shera, rather than observing the sociopolitical reality and technical partner in which the texture of a library-based thought (but visualized by him as documentaryinformational), establishes, in his own praxis, social epistemology as a sort of "critique of the future," that is, as a praxis of the reflexive activity of the subject inserted in this episteme. In our discussion, the epistemological-social approach represents a vanguard for the context of its affirmation, a reassessment for the immediate decades to its presentation (years 1960 and 1970) and a critique for the future of what was consolidated under the notion of information Science, anticipating affirmations of "social nature" of the 1980s and 1990 s in the field of information.
\end{abstract}

Keywords Jesse Shera. Social Epistemology. Historical Epistemology. Philosophy of Information. Information Science.

Rojas (1996): the triadic reconstruction of the past of an episteme that, from the $1960 \mathrm{~s}$, embraces the term information as its central unit of analysis tends to remove from the epistemological records the problematic launched by Shera's bias. Shera's (1983) recollection of the Pieta, rather than the mechanistic focus of Shannon and Weaver, seems to be the critique of the future envisaged in his social epistemology, open to the plurality of the world of art and culture, as well as to the interpretations of symbolism of the social construction of our space-time.

Even with the twists and turns of the neodocumentalist movement, demarcated in perspectives such as those from Rayward (1996), Buckland (1991) and Frohmann (2011, 2009, 2004), this condition of concealment of a theoretical construct seems intact: criticism of the epis- 
temology of information remains as the attempt to reposition the life and work of Paul Otlet and his followers. Shera's tradition is largely absent in this retrospective reflection. Even contributions that are objectively related to Shera's ideas in the last 20 years of historiographical criticism, to which it was agreed to treat of "Information Science" in Brazil, are configured according to brief approximations and sparse dialogues.

Curiously, in the midst of the presence and absence of his thought in the historiographical construction of the Library and Information Science-informational field, Jesse Shera was also (and probably one of the main) theorists dedicated to understand the sedimentation ideas of such field. The American theorist, while establishing one of the great conceptual units of informational studies, enters the swampy debate about how it was actually effected in theoretical and institutional terms, what has now become known as library and Information Science or Information Science from the 1960s in the United States and later on in the world. Shera is thus a central figure in the context in which many discourses of passage, of paradigmatic fracture, of epistemological mutation in the field, that is, the 1950 s and 1960s context, generally signified by expressions correlated to "post -war".

The objective of the work, given the relevance of Shera's thought and its repercussions, is to reposition, in epistemological-historical terms, Jesse Shera's approaches and their impacts in the contemporaneity. The purpose of the discussion is to understand, in a philosophical-pragmatic way, some unequivocal relations between Shera's critique for the context of its theoretical formulation and the consequences of this approach, contrary to some tendencies from the technical roots of the field. From the reflection, it is possible to deduce, to a certain extent, how Shera, rather than observing the socio-political reality and technical part in which the texture of a (so) librarianship-based thought (but visualized by him as documentary-informational), establishes, in his own praxis, social epistemology as a sort of "critique of the future," that is, as a praxis of the reflexive activity of the subject inserted in this episteme.

The interpretative possibility can be recognized in Luciano Floridi's (2004) epistemological position and his search to establish a philosophical infrastructure of the field, having Shera's social epistemology as a counterpoint. Ian Cornelius's (2004) critique of such an epistemological quarrel, at the end of the reflection, expresses how recent approaches, treated both as "social", sometimes as pragmatic, sometimes as linguistic, sometimes as symbolic, "rediscover" what is more original in the position of Jesse Shera, in the creation and praxis of a social epistemology.

For the development of the reflection, in a first moment, we revisited the traditionally recognized issues of demarcation of the epistemological frontiers of what was considered Information Science, entering into the thinking of the "historian Shera" who experienced the praxis of technological change. In a second moment, we approach the scene of "Shera epistemologist", seeking to point to his reflection on the praxis experienced. The course leads us to the contemporary considerations of historiographical criticism and to Shera's symbolic bias.

\section{Terminological and historical problems before the war}

In 1968, Harold Borko published in the American Documentation the definition of Information Science taken from Robert Taylor, who notably exerted much influence on the definitions to come as well as the production of knowledge in the area in the following decades. According to Borko, Information Science could be understood as:

Information Science is that discipline that investigates the properties and behavior of information, the forces governing the flow of information, and the means of processing information for optimum accessibility and usability. It is concerned with that body of knowledge relating to the origination, collection, organization, storage, retrieval, interpretation, transmission, transformation, and utilization of information. This includes the investigation of information representations in both natural and artificial systems, the use of codes for efficient message transmission, and the study of information processing devices and techniques such as computers and their programming systems. It is an interdisciplinary science derived from and related to such fields as mathematics, logic, linguistics, psychology, computer technology, operations research, the graphic arts, communications, library science, management, and other similar fields. It has both a pure science component, which inquiries into the subject without regard to its application, and an applied science component, which develops services and products (Borko, 1968, p.3)

In this definition, we can see that Borko endeavored to highlight the various characteristics of this science. First, the author demonstrated the fundamental object of studies of Information Science, that is, the very concept of information, its properties and behavior. Then, he listed the main fields of action and applications of Information Science: "[...] that body of knowledge relating to the origination, collection, organization, storage, retrieval, interpretation, transmission, transformation, and utilization of information. (Borko, 1968, p. 3)"'.

In Information Science: What is it?, Borko clearly demonstrates his personal and scientific motivations to address a definition of Information Science. At the beginning of this explanation, the author states that this is not a definitive answer to the question "What is it?", but rather an effort to try to explain the making of this science and of the agents acting in this field (Borko, 1968 , p. 3). Thus, Borko demonstrates that the initial 
motive for such a task came after the American Documentation Institute decided to rename the American Society for Information Science in 1968. Due to this change, Borko and his peers were forced, in the personal and professional field, to explain what this science would be and how it relates to Documentation and Library Science (Borko, 1968, p.1).

It can be seen that Borko's definition was elaborated at a time when a possible science for information sought to assert itself distinctly and fought for a scientific status. It is appropriate to consider that the definition presented by Borko - a non-original definition, since it referred to the meeting of the Georgia Institute of Technology in 1961 - and its year of publication, 1968 (Great transformations in the American Library Science) ended up having a great acceptance in Information Science. As Bates (1999) points out, Borko's definition remained stable and widely accepted for at least the three decades following its publication.

However, the wording developed at Georgia Institute of Technology was developed jointly, not being attributed to a specific author or group. Thus, the compilations of these conferences elaborated by Robert Taylor and published in 1966 in the Annual Review of Information Science and Technology (ARIST), in an article entitled "Professional aspects of Information Science and technology", can be considered of great relevance since, as Borko admits, were the bases for the elaboration of its definition, as can be evidenced in the following comparison:

The science that investigates the properties and behavior of information, the forces governing the flow of information, and the means of processing information for optimum accessibility and usability. The processes include the origination, dissemination, collection, organization, storage, retrieval, interpretation, and use of information. The field is derived from or related to mathematics, logic, linguistics, psychology, computer technology, operation research, the graphic arts, communications, Library Science, management, and some other fields (Taylor, 1966, p.19).

Through these comparisons, it is possible to perceive that Borko's additions were minimal, having emphasized the relations between Information Science and Informatics and deployed some considerations about the interdisciplinary character of the field. However, it is necessary to take into consideration that these definitions were being published in an initial period of the establishment of the term "Information Science", where the spaces for the discussion of their nature were very evident, at the same time that the expression Library and Information Science was also adopted to mean the field in affirmation (as it is until the present day in the United States).

It is not fortuitous to conceive the idea that Information Science would have arisen in the 1960s without any kind of theoretical, professional or even scientific background. As Saldanha (2010) points out, a considerable part of the literature of the area on the emergence of Information Science, reinforces, by weaving a kind of chronology, but not of historiography, Kuhnian's notion that Information Science established after a process of paradigm breaks, largely disregarding the efforts and studies in the field of information previously performed (Saldanha, 2010, p.301).

In this historiographical line, there seems to exist nothing before the neologism "Information Science" in the plane of these studies, if not paradigms annulled, obsolete theories before the new socio-technical demands of the postmodern world, or even pseudo-disciplines, as if what we know from the fragile margins of the idea of "Information Science" to represent an enlightened scientific structure. It is a line that is confused by identifying Information Science "pioneerism" with the emergence of the very term "Information Science" within the scope of knowledge organization studies and sometimes makes us imagine, by the fascination of language, that the institutionalization of it and its legitimation is the structural source of a "new" science for a "new" thought in the tree of specializations. Part of this historiographical view is based precisely on the idea of interdisciplinarity, as opposed to the departmentalization of nineteenth-century science, when in fact the philosophical presuppositions of a possible "new" area were fundamentally based on the idea of a positivist and technicist specialization to investigate information. (Saldanha, 2010, p.301, our translation).

Although widely used, Borko's notion cannot be considered a unanimity, either in the contemporary context or in the academic productions of the final decades of the twentieth century. This becomes evident when analyzing the works of authors who were already involved in activities and theoretical discussions related to information such as Jesse Shera and Donald Cleveland. In the article History and Foundations of Information Science the authors focused on events, actions and the development of theoretical assumptions and fields related to Information Science existing before the official formalization of the foundation.

Shera and Cleveland begin the discussion of the formation of Documentation, since, according to them, in the late nineteenth century the problem of a large production and circulation of bibliographic documents was becoming very serious (Shera; Cleveland, 1977, p.250). This situation led Paul Otlet and Henri La Fontaine to form the IIB, International Institute of Bibliography in 1892, renamed the International Institute of Documentation in 1931 (Shera and Cleveland, 1977, p.251).

Gradually, what is constituted under the notions of bibliography and documentation was extended around the world in order to promote and facilitate the access by users, primarily scientists and university students, to all kinds of documents, especially those that were not books (Shera and Cleveland, 1977, p.250). However, the Documentation was not structured homogeneously

Bozzetti, Rodrigo Porto; Saldanha, Gustavo. Jesse Shera, the Wars and the Pietá: social epistemology as criticism of information ontology. // Brazilian Journal of Information Studies: Research Trends. 11:2 (2017) p.79-87. ISSN 1981-1640. 
in the world. In the 1920s, and especially in the 1930s, at least two Documentation schools were established, a French one, based on the works of Paul Otlet, Henri La Fontaine and Suzane Briet, and the other would be the American school (although "small" near what was consolidated under the notions of Information Science and Library and Information Science throughout the 20th century) that was established around some important institutions in the United States as the Library of Congress, the American Library Association and the American Documentation Institute (Shera and Cleveland, 1977, p.252-253).

Shera and Cleveland show that, unlike most sciences and fields of study, Documentation in the American way was not international in scope, with the French school having influenced the development and establishment of practices and the teaching of Documentation throughout Europe, in India through Ranganathan and in Latin America (Shera and Cleveland, 1977, p.250). Although authors do not dwell on the possible origins of this low international reach and wide French influence, it is important to remember that this occurred in a pre-World War II scenario, when the United States did not exercise such a strong influence around the world on several aspects and the English language was not so widespread at the time.

However, they both go on to explain why the US Documentation has become significantly different from the French one and has adopted practices that are not widely considered around the world. The reasons for the formation of an American School of Documentation would be linked to the dissemination of inexpensive forms of photographic reproduction. Due to the development of fine-grained photographic emulsions and the development of cameras that used $35 \mathrm{~mm}$ negatives of non-explosive base acetate, technologies developed by Kodak, allowed libraries to reproduce their collections on a large scale. (Shera and Cleveland, 1977, p.252).

Soon, this technology became widely used by librarians and documentarians; some conferences of high relevance of photographic reproduction were carried out; a journal called the Journal of Documentary Reproduction was created and academic discussions arose on the use of microfilmed material, which supposedly would have the power to replace the book (Shera and Cleveland, 1977, p.252). This was a discussion that closely resembles the dissemination of electronic media in the early 21 st century. In other words, we are faced with the theoretical idea of mechanism, the same that focuses on Taylor and Borko's definition of the expression Information Science in the 1960s.

\section{The theatre of war: the new political economy and the prevalence of the mechanistic model}

In the context of the development of documentary discourse in the United States, in 1937, one of the largest organizations associated with Documentation, the American Documentation Institute (ADI), was created, initially having as purpose, various actions related to reproduction and dissemination of documents through photographic reproduction (Shera and Cleveland, 1977, p.254-254).

Soon after ADI's creation, the dynamics of American political economy changed rapidly and very significantly, directly related to World War II. Traditionally, the date the conflict began was first of September of 1939, day in which Germany invades Poland, putting in practice a policy of annexation of territories that was already in force for some years and dominates part of this country in about 2 weeks (Oxford, 1995, p.891).

The United States official participation in the conflict is only recognized on December 7, 1941, the date of the Japanese air force attack on Pearl Harbor in the American territory of Hawaii. However, historiography points out that American involvement in favor of French and English had already occurred at least since 1939, as well as veiled hostilities to Japanese and Germans (Lens, 2006). Thus, long before the attack on Pearl Harbor, the United States was already deeply involved in the conflict, especially in the economic field. American industrial production began to grow on a large scale as more and more American products were sent to the British war effort.

Given the large scale of the conflict, as well as the high degree of economic and political interests, it is not appropriate to consider that the dynamics of the techniques and theories established under the notions of Library Science and Documentation have not been strongly impacted, mainly due to the character of these fields at a time of high technological production. It is not unfounded that Shera and Cleveland made recurrent allusions to World War II in the elaboration of the discourse of a certain Information Science.

One of Shera's and Cleveland's most relevant allusions to the conflict is the manifestation of Jesse Shera's activities (acting as librarian, documentarian and / or information scientist) in the Office of Strategic Services (OSS) Central Information Division (CID). Both do not explain the OSS acronym in the text, perhaps because its meaning is understandable to american readers, since the OSS was not a governmental organization of low importance in the period.

The OSS was an intelligence agency formed in the United States during World War II inspired by the English molds due to the urgent need of this country to 
process and organize information of a confidential nature (Oxford, 1995, p.822). This organization was instructed by the president to collect and analyze information considered strategic (Oxford, 1995, p.832), including a committee for the acquisition of foreign journals (Committee for the Acquisition of Foreign Periodicals) as well as a research and development group. (Oxford, 1995, p.833).

The OSS participated in missions in almost all the theaters of war that unfolded after its official creation in June 1942. Although its existence was short, being abruptly closed in September 1945, this agency remained an important instrument since it was the basis for institutionalization of CIA (Central Intelligence Agency) in 1947 (Oxford, 1995, p.833).

In this way, the librarian Shera, who between 1940 and 1941 had been the head of the Census Library Project headed by the largest library in the United States, the Library of Congress, became part of the OSS in 1941, when it was called the Office of the Coordinator of information), created in July 1941 through the Central Information Division (Wedgeworth, 1993, p, 774). Thus, during the worldwide conflict of such great impact on American society, Shera began to work in one of the largest organizations that worked with information in the country and in a sector of great strategic importance.

In a detailed way, the OSS acquired, indexed, and analyzed a wide range of documents, such as telegrams, letters and memoranda. From these materials, maps, reports and graphs were generated among other studies that were sent to US military and political authorities. The OSS team was made up of workers from areas such as economics, history, geography, social sciences, and others, all of whom were chosen according to the criteria of the Director of General Agency William Donovan (Heaps, 1998, p.289).

Such information was processed in the CID, where Jesse Shera was the head of the reference industry (Heaps, 1998, p.289). This division was of great relevance to the success of the OSS operations, since, even in the early days of the agency, its director requested the creation of an index that would allow indexing of the documents that arrived daily at the OSS. Between 1941 and the beginning of 1942, a system was developed to create links between the document itself and the individuals who wanted to have access to the information contained therein, i.e. a system of information retrieval (Heaps, 1998, p.291-292). The indexing was done through cards. First, the documents were numbered according to the order of arrival. Then other cards were prepared to register and cross information through terms such as name, subject and country. After this, the indexer briefly summarized the subjects dealt with in the document (Heaps, 1998, p.291).
The system was considered, at the time, one of the best in the United States (Heaps, 1998, p.291-292). However, the CID started increasing $400 \%$ the number of documents received between January 1942 and December of the same year. In early 1943, indexers were no longer able to index all documents. The OSS began to make frequent requests for more indexers that, according to Shera, carried out professional work and had a good degree of historical knowledge and international conditions (Heaps, 1998, p. 296).

In addition to carrying out work of profound economic and political importance worldwide, due to the high degree of secrecy of the documents stored and indexed by this intelligence agency, Shera was also having firsthand contact with new technologies for information retrieval and indexing.

But a more important development from the standpoint of the emergence of Information Science was the early work being done in several government agencies on the subject analysis of documents using punched-card IBM equipment. At the Central Information Division of OSS, J. H. Shera and his associates were experimenting with primitive techniques for idexing censorship intercepts of mail from abroad. (Shera and Cleveland, 1977, p.254, our translation).

It is also interesting to note the prominence given to IBM punched-cards, first developed in the late 19th century by Herman Hollerith. These cards, as well as their reading machines, which are real mechanical computers, have become popular because of their potential to rapidly carry out operations that took years before (Black, 2001, 22-23).

In other words, in addition to the photographic reproduction techniques described above, the technologies related to the indexing of information through punched-cards were also important for the establishment of an American Documentation School (or for the development of mechanics of Library Science, already considered advanced in 1870, as demonstrated in Otlet (1934)). During the troubled context of World War II, it is not an overstatement to say that the production of knowledge, in all areas was very low in France. In the field of Documentation, it was no different, since, although the National Library of France was not closed, Suzanne Briet and her colleagues faced an oppressive atmosphere of censorship, fear and dismemberment of collections perpetrated by the Nazis. Briet's projects functions were interrupted and the French National Library greatly reduced its productivity (Maack, 2005).

\section{The other economy of war: information as a cold weapon}

The end of World War II, as well as the 15 years that separated the termination of this conflict from the definitions of Georgia Tech, represented the breakthrough in the development of experiences with information 
processing during the conflict. The Documentation, although after a period of great growth during the great war, would have fallen in frank decline easily remarked by ADI's membership, which had its number of associates reduced from a few thousand to 200 in the early 1950s, and only 75 in 1957 (Shera and Cleveland, 1977, p.256).

However, after the great impetus of World War II, another conflict front objectively influenced the development of mechanistic experiments under the notions of Library Science and Documentation. In the new world context, the Cold War, the United States, and the Soviet Union have come to contest global geopolitical positions. In the unfolding of the division between the capitalist and socialist blocs, the Soviet Union launches the first satellite to space in 1957, called Sputnik.

The Soviet "conquest" caused the United States to strive to accomplish a similar or superior feat (economically and symbolically). The American government organized a large task force that brought together several highly relevant bodies in the country, mainly from a scientific and technological point of view, such as the Massachusetts Institution of Technology, IBM, National Library of Medicine, Kodak, National Science Foundation and ADI. This meeting of large organizations led ADI to return to a larger number of members (Shera and Cleveland, 1977, p.257).

However, such an effort would have made the notion of documentation, at least in the United States, fall into disuse. After the International Scientific Information Conference held at Washington in 1958, many people from other areas would have first come into contact with the "Documentation" (Shera; Cleveland, 1977, p.257). However, ten years later, the process of terminological transformation objectively "extinguished" the notion as a macro concept in American territory: ADI changed its name to ASIS (American Society for Information Science).

It is interesting to note that, for Shera and Cleveland, the formation of Information Science in the United States did not consist only of a name change, but both admit that much of the discussion in the Documentation was inherited by Information Science. Moreover, noteworthy is the weight the authors confer on the participation of the most varied US federal organizations for an indirect contribution to the formation of Information Science (Shera and Cleveland, 1977, p.258).

The authors also point out that the cooperation from the launch of Sputnik to help solve the "information problem" was not exactly new, since during World War II technical and scientific cooperation took place on a large scale. However, little attention was paid to methods and devices of bibliographic control and dissemination of information (Shera; Cleveland, 1977, p.258).
In addition, the authors indicate that, unlike the 1940s, which relied on purely mechanical computers with very few electrical or electronic parts, in the 1960s they became information processing machines rather than large calculators (Shera and Cleveland, 1977, p.259). The development of these machines ended up having a role and relevance for the consolidation of Information Science. However, it is necessary to recognize Shera's vision before and after the consolidation of the notion of Information Science, as a critique of the mechanic process, a reflection of the development of the field. Here is the central role of his notion of "social epistemology" as a critical tool for "technological dependence".

\section{The "social" in the epistemology of information science: on the way to social epistemology and the critique of the future}

The discussion developed by Jesse Shera and Margaret Egan during the search for a distinct epistemological frontier for library practices from the 1950s onwards, underscores the critical role of Shera's historical view. The epistemology in question would be oriented to the structure of effective investigation of the complex problems of intellectual processes of knowledge formation, but under the understanding of the social construction of the information facts.

The Social Epistemology, presented in the publication Foundations of a Theory of Bibliography, still evidences a list of interpretative possibilities, approached by Fallis (2002), Oddone (2007) and Zadonade (2004), Araujo, Lage, Souza and Assis 2010) and Marteleto (2015). In Fallis's view (2002), the construction of what we now, treated as Information Science, would represent a laboratory of application of theories of a social epistemology - in direct terms, we are faced with a completely different demarcation of an epistemology for information from that presented by Taylor and Borko.

To amplify the delicate historiographicalterminological dynamics of the field, the Social Epistemology is launched in a scientific journal of Librarianship, whose scope is Bibliography. This is a broad "Bibliography", linked to both a Textual Bibliography and a Statistical Bibliography. In other words, Social Epistemology demonstrated itself far beyond the terminological problems of defining the area, beyond its epistemological limitations, beyond (at last) its social meanings. It was oriented to the set of knowledge and practices linked to studies of the organization of knowledge and conferred, for example, the term "librarianship" and the term "bibliography", a very broad and diverse semantic condition.

In addition to the issues under the concept of social epistemology, Shera (1970), in a timely dialogue with the thinking of Shiyali R. Ranganathan, presents his

Bozzetti, Rodrigo Porto; Saldanha, Gustavo. Jesse Shera, the Wars and the Pietá: social epistemology as criticism of information ontology. // Brazilian Journal of Information Studies: Research Trends. 11:2 (2017) p.79-87. ISSN 1981-1640. 
Sociological Foundations of Librarianship, where he deepens the discussion opened 20 years earlier, alongside Egan. Shera's view raises the issue of the central elements in the construction of an epistemologicalsocial perspective, namely: the social role of the librarian, the relationship between library thinking, knowledge and society registers, the central relevance of language in field, the notion of library as a social construction, co-constitution relations between culture and library institutions.

What we recognize in the expression "social epistemology" is the problematization of the informational practice from its social justification. Cataloging, classifying, preserving are gestures taken as technical tasks institutionalized by a philosophy of problem solving in society. Thus, epistemology of the field is a product of a social process, communication. Thus, in the social study, it is the analysis of the dynamics of the organization of knowledge, the unilateral idea of mathematical control or the final definition of the forms of acquisition, storage and dispersion of artifacts. Mechanism is here a theoretical byproduct. Phenomena, including those of a technical nature, can only be understood in their transformation condition, in their living and changing reality, in their experience.

The praxeology is thus established with social epistemology as the gnoseological basis for the "so" Library Science, for the Documentation and for the Information Science (or for the "name" that comes to guide the praxis evidenced). Shera (1973) calls attention to the process and mode of social constitution of the field. The scope of "future" "informational studies", according to the author, should encompass both the individual's cognitive system and his or her communication network.

Given this, Social Epistemology would be a philosophy of the sciences that deals with knowledge in its experience in the social structure of collective construction of individuals, in addition to representation, taking language as action, anticipating deep contemporary discussions linked, for example, to the study of Social networks and cultural studies of use and sharing of information.

The author goes from the institution that represents one of the most fruitful conceptual metaphors of the area: the library. This is a social construction, which makes us reflect that all knowledge takes place through subjective transversalities. In the midst of these transversalities, the librarian - or bibliographer, or documentalist, or scientist / information professional - is positioned as an interpreter from a complex of contexts. The ultimate purpose of communication lies on the notion of understanding (Shera, 1973).

The object of study of social epistemology becomes the individual in his community, or society itself. To inves- tigate these groups of individuals, such epistemology would seek to understand the complex dilemma of knowledge; the way society perceives and apprehends the world. The focus of this discipline would be the production, flow, integration and consumption of all forms of communication in its social fabric (Shera, 1973).

Social epistemology should provide the disciplines of information, such as bibliographic systems, with the assumption that constructions of information mediation start from social constructs, and must encompass the problem of cognition, or how man learns; the problem of social cognition, or how society learns; and the history and philosophy of knowledge existing in different cultures, or how society transformed its knowledge into memory, and how this same society interprets its safeguarded knowledge. Shera's sociological view points to the definition of the library as a social agency (Shera, 1970, p.60), oriented toward structural relations between social macro-institutions such as state, family, religion and law. In its praxis as a social agency, the library assumes, given the foundational role of language in its socio-historical constitution, the scope of an agency of communication (Shera, 1970, p. 68), emphasizing the mediating role of the librarian.

Therefore, the epistemological-social approach critically addresses the definition of a total informational ontology: it stands in the way of an information philosophy centered on the role of technologies as independent tools, or potentially neutral, or even capable of transparent demarcation in their actions. All mechanism is placed as a social product, historically and symbolically woven. In Shera's words (1970: 85-86), social epistemology is the study of knowledge in society. In other words, social epistemology is primarily a critique of the philosophy of information, and of the affirmation of this practical philosophy as central to social development in the decades after 1950.

According to Budd (2002), in Shera's thinking, social epistemology could provide general theoretical foundations that have always been the concern of informational studies. This epistemology would be based on the notion of communication. Unlike the traditional epistemology, focused only on the formation of the researcher, the knower away from the object and the search for truth, Shera's action program would be structured in the look at the mechanisms of communication between scientists. This approach holds that social epistemology and general semantics - that is, a specific approach to language analysis - move close together and are built within the epistemology of Information Science. Thus, Social Epistemology is also, to use Wittgenstein's words (1979), a critique of language.

Shera therefore adopts a program that investigates the rationale for situated beliefs and the social outcomes that circumscribe the collective development of indi-

Bozzetti, Rodrigo Porto; Saldanha, Gustavo. Jesse Shera, the Wars and the Pietá: social epistemology as criticism of information ontology. // Brazilian Journal of Information Studies: Research Trends. 11:2 (2017) p.79-87. ISSN 1981-1640. 
viduals, together with external factors that affect this growth. Such an epistemologist examines the constitution of contexts / situations, that is, the formation of the social situation in which knowledge is woven. For Shera, the study of the mediation act does not cover only the examination of discrete actions, but the investigation within the epistemological bases of the process, a plural hermeneutic, as Capurro (2003) will defend.

\section{A critical of the future: final considerations}

We recognize that it is in the context of the advancement of statistical applications of information gathering in quantitative approaches that Shera's social epistemology is launched and developed alongside Egan's thinking. More than this, we have identified that, historically, Shera was objectively involved with such applications, that is, with the elaboration of an objective mechanistic approach to the organization of knowledge. Beyond such constraints, the concept is presented in a radical geopolitical landscape, marked by great mutations and social uncertainties.

Thus, the epistemological-social approach indicates a vanguard for the context of its affirmation, a reevaluation for the immediate decades to its presentation (years 1960 and 1970), and a critique for the future of what has consolidated under the notion of Information Science, anticipating "social" statements of the 1980s and 1990s in the informational field, as well as linguistic-pragmatic approaches, such as those with Wittgensteinian influence, as present in authors such as Frohmann and Capurro in the 1990s onwards.

Shera will both recover the philological analyzes of the knowledge organization and anticipate a discussion that will become increasingly present in the works that doubled the 1970 s to 1980 s, and whose structure became more consistent in the last decade of the twentieth century. It is clear, therefore, in Shera's thought, the search for an amplification of the "future cognitivephysicalist approaches" of Information Science, for him, already recognized there.

We can also recognize social epistemology, in the time-space of its construction and in Shera's biographical landscape, as a kind of (historical) historiographic criticism. With its vocabulary, the notion finds terms such as culture, collective behavior, action, practice, social organization, complex organization, social utility, understanding, society, acculturation, pointing to a pragmatic-sociological discourse, interested in the social construction of informational artifacts, which is already lacking in reflection and will become, in the following decades, emerging (now called "novelties").

Social epistemology also becomes a conceptual mechanism for understanding the epistemic struggles of the construction of the discourse of the field and its future attempts to affirm general theories of information, the dispute for the monopoly of definition, demarcation, the frontiers of what has passed to be treated as Information Science receives, under the shadow of social epistemology, critical reflection on its risks and potential misunderstandings (such as the abandonment of theoretical and social premises).

In short, from social epistemology, Shera dialogues with the past, present and future of informational thinking, anticipates the risks of an informational ontology, establishes a "premonition" of the socio-cultural urgency of symbolism in the informational epistemology of the field, affirming the a-ontologically, structurally logological (discursive), from the "social" predication for Information Science, and, finally, points to the absence of the dialectic "science and society" as a tool of demarcation of "social-informational" before a permanently transformed world by extreme economicpolitical conditions such as World War II and the Cold War, a world that might conceal the ambiguous beauty and affirmation of the symbolic beyond and beyond the war present in Pieta.

\section{References}

Araújo, C. A.; Lage, D. F. de S.; Souza, R. M. F; Assis, R. A (2010). A contribuição de J. H. Shera para a Ciência da Informação no Brasil // Revista ACB: Biblioteconomia em Santa Catarina, Florianópolis, $15: 2$ (jul./dec, 2010) 71-89.

Bates, M. J. (1999). The Invisible Substrate of Information Science // Journal of the American Society for Information Science. 50:12 (1999) http://pages.gseis.ucla.edu/faculty/bates/substrate.html 1043-1050.

Black, E. (2001). IBM e o Holocausto. Rio de Janeiro: Campus, 2001 .

Borko, H. (1968). Information Science: what is it? // American Documentation 19:1 (1968) 3-5.

Buckland, M. K. (1991). Information as thing. // Journal of the American Society of Information Science. 42:5 (June 1991) 351-360.

Budd, J. M. (2002). Jesse Shera, social epistemology and praxis. // Social Epistemology. 16: 1 (2002) 93-98.

Capurro, R. (2003). Epistemologia y Ciencia de la Información. // Anais do Encontro Nacional de Pesquisa em Ciência da Informação, 5, 2003, Belo Horizonte: Escola de Ciência da Informação da UFMG, 2003.

Cornelius, I. (2004). Information and its philosophy // Library Trends. 52:3 (win. 2004) 377-386.

Fallis, D. (2002). Introduction: social epistemology and Information Science // Social Epistemology 16:1 (2002) 1-4.

Floridi, L. (2004). Afterword library and Information Science as applied philosophy of information: a reappraisal // Library Trends. 52: 3 (2004) 658-665.

Frohmann, B. (2004). Documentation redux: prolegomenon to (another) philosophy of information. // Library Trends, 52: 3 (win.2004) 387-407.

Frohmann, B. (2011). Reference, representation, and the materiality of documents // Colóquio Científico Internacional da Rede Mussi. 2011. Anais. Toulouse: Université de Toulouse 3, 2011. 
Frohmann, B. (2009). Revisiting "What is a document?" // Journal of documentation. 65: 2 (2009) 291-303.

Heaps, J. (1998). Tracking Intelligence Information: The Office of Strategic Services. // The American Archivist 61:2 (1998) 287-308.

Lens, S. (2006). A fabricação do Império Americano. Rio de Janeiro: Civilização Brasileira, 2006.

Maack, M. (2005). The Lady and the Antelope: Suzanne Briet's Contribution to the French Documentation Movement. Los Angeles: UCLA, 2005

Marteleto, R. (2015). Epistemologia social e cultura digital: reflexões em torno das formas de escritas na web // Em Questão 21:3 (sep/ dec. 2015) 9-25.

Miksa, F. L (1992). Library and Information Science: two paradigms // Vakkari, P.; Cronin, B. (eds.). Conceptions of Library and Information Science. // Proceedings of the international conference of the celebration of 20 th anniversary of the Departament of Information Studies, University of Tampere, Finland, 26-28.

Oddone, N. (2007). Revisitando a "Epistemologia Social": esboço de uma ecologia sociotécnica do trabalho intelectual // Ci. Inf., Brasília. 36: 1 (jan/apr.2007) 108-123.

Otlet, P. (1934.) Traité de documentation: le livre sur le livre: théorie et pratique. Bruxelas: Editiones Mundaneum, 1934.

Oxford University (1995). The Oxford Companion to World War Two. Oxford: Oxford University Press, 1995.

Rayward, W. B. (1996). The History and historiography of Information Science: some reflections // Information and Management. 32: 1 (1996) 3-17.

Rendón Rojas, M. A. (1996). Hacia um nuevo paradigma em bibliotecologia // Transinformação. 8: 3 (sep./dec. 1996) 17-31.
Saldanha, G. S. (2010) Tradições epistemológicas nos estudos de organização dos saberes: uma leitura histórico-epistêmica a partir da filosofia da linguagem // Liinc em Revista. 6:2 (2010) 300-315.

Shera, J. H. (1983) Librarianship and Information Science // Machlup, F.; Mansfield, U. (eds.) The Study of Information: Interdisciplinary Messages. New York: Wiley, 1983.

Shera, J. H.; Cleveland, D. B. (1977). History and Foundations of Information Science // Annual Review of Information Science and Technology 12 (1977) 249-267.

Shera, J. H. (1973). Toward a theory of librarianship and Information Science // Ci. Inf. 2:2 (1973) 87-97.

Shera, J. H. (1970) Sociological Foudations of Librarianship. London: Asia Publishing House, 1970.

Taylor, R. (1996). Professional aspects of Information Science and technology // ARIST- Annual review of Information Science and Technology 1 (1996) 15-40.

Wedgeworth, R. (1993). World Encyclopedia of Library and Information Services. Washington: American Library Association, 1993.

Zandonade, T. (2004) Social Epistemology from Jesse Shera to Steve Fuller// Library Trends 52: 4 (Spring 2004) 810-832

Copyright: (C) 2017. Bozzetti, Saldanha. This is an open-access article distributed under the terms of the Creative Commons CC Attribution-ShareAlike (CC BY-SA), which permits use, distribution, and reproduction in any medium, under the identical terms, and provided the original author and source are credited.

Received: 2017-01-30. Accepted: 2017-05-18 